\title{
Remote Sensing \& GIS Based Spatio-Temporal Change Analysis of Wetland in Dhaka City, Bangladesh
}

\author{
Mallik Sezan Mahmud*, Arif Masrur, Asif Ishtiaque, Fouzia Haider, Ummai Habiba \\ Department of Geography and Environment, Faculty of Earth and Environmental Sciences, \\ University of Dhaka, Dhaka, Bangladesh \\ E-mail: "sezan3000@yahoo.com
}

Received August 9, 2011; revised September 29, 2011; accepted October 31, 2011

\begin{abstract}
Landscape of Dhaka city - one of the fastest growing mega cities in the world, is continuously changing due to un-planned urbanization. For example, the wetlands of the city have been shrinking. This study evaluates wetland changes in Dhaka Metropolitan Area (DMA), Bangladesh, between 1978 and 2009. Spatial and temporal dynamics of wetland changes were quantified using four Landsat images, a supervised classification algorithm and the post-classification change detection technique in GIS environment. Accuracy of the Landsat-derived wetland maps ranged from $87 \%$ to $92.5 \%$. The analysis revealed that area of wetland and Rivers \& Khals in Dhaka city decreased significantly over the last 30 years by $76.67 \%$ and $18.72 \%$ respectively. This changing trend of wetlands makes the drainage system of Dhaka City vulnerable, creating water logging problems and their consequences. Land filling and encroachment were recognized to be the main reasons for shrinking of the wetlands in the city. Development and alteration of the existing water bodies should consider the natural hydrological conditions.
\end{abstract}

Keywords: Wetlands, Remote Sensing, GIS, Dhaka City, Bangladesh, Change Analysis

\section{Introduction}

Dhaka City has been suffering from many environmental problems including flooding, water logging and other related problems. In the past the City was regarded as the Venice of the East or the City of Channels [1]. A few decades ago there were numerous lowlands, Khals and channels within and around Dhaka that would drain the City efficiently [2]. Khals of the city are used to be the connecting channels of the rivers surrounded by the greater Dhaka [3]. But nowadays, the situation is completely different. The City has spread over the years in all directions and such expansion has caused shrinkage of the natural drainage and wetlands [4]. Moreover, most of the khals have disappeared and banks of the surrounding rivers are encroached and/or grabbed gradually due to a number of reasons. The major causes are unplanned urbanization, encroachment, lack of co-ordination between government agencies, maintenance to the system and implement of pertinent laws [5]. As a result each year the city dwellers suffer acute water logging problems during the rainy season. In a report on Strategic Environment Assessment of Dhaka, water logging has been identified as one of the major problems of the City [6]. During monsoon rains, many areas of Dhaka go under water, because canals, being the primary drainage system of the city are blocked, cannot carry the huge volume of storm water [7]. The situation has turned very severe in recent years, and main streets now go under a meter of water after heavy monsoon shower [8]. There is no single authority for the management of wetlands in Dhaka City, thus creating a lack of coordination among the related organizations. Because water logging is one of the major problems of the City, there is an immediate need to implement land use regulations and strict enforcement mechanisms, restrictions to the land encroachment on the bank of the Khals in the city and implementations of cities' urban and drainage master plans [9]. On the other hand, there is no specific map or well-documented records of wetlands of the City. The land grabbers take this opportunity to encroach the wetlands [10]. It is urgent to identify the wetlands, evaluate its trend of changes and their consequences on the wetlands. The aims of this study therefore were to identify the past and present spatial extent of wetlands, their changing patterns during 1978-2009, and the physico-environmental consequences 
on the area.

\section{Study Area}

Dhaka Metropolitan Area (DMA) is the study area of this study and it is located between longitude $90^{\circ} 20^{\prime} \mathrm{E} \&$ $90^{\circ} 30^{\prime} \mathrm{E}$ and latitude $23^{\circ} 40^{\prime} \mathrm{N} \& 23^{\circ} 55^{\prime} \mathrm{N}$ (Figure 1). The total area of Dhaka Metropolitan Area (DMA) area is $306 \mathrm{~km}^{2}$ [11]. Total population is about 9.3 million [12]. Rivers all around bound the periphery of Dhaka. The strategic location of Dhaka connects it with the rest of the country with a network of rivers. At the beginning of urbanization, this region took the advantages of this river system at full extent [13]. The river Buriganga lies in the south, the Balu River in the east and the Turag River in the north and west. James Rannell, who surveyed the rivers of east Bengal in 1765, wrote "the kingdom of Bengal, particularly the eastern part, is naturally the most convenient for trade within itself of any country in the world; for the rivers divided into such a number of branches that the people have the convenience of water carriage to and from any principal place” (letter from J. Rannell to the Reverend Gilbert Barrington, Vicar of Chudleigh, Devon, cited in Ahmed, 1986). Dhaka being situated in the center of the then east Bengal had a significant command on all these water routes [14].

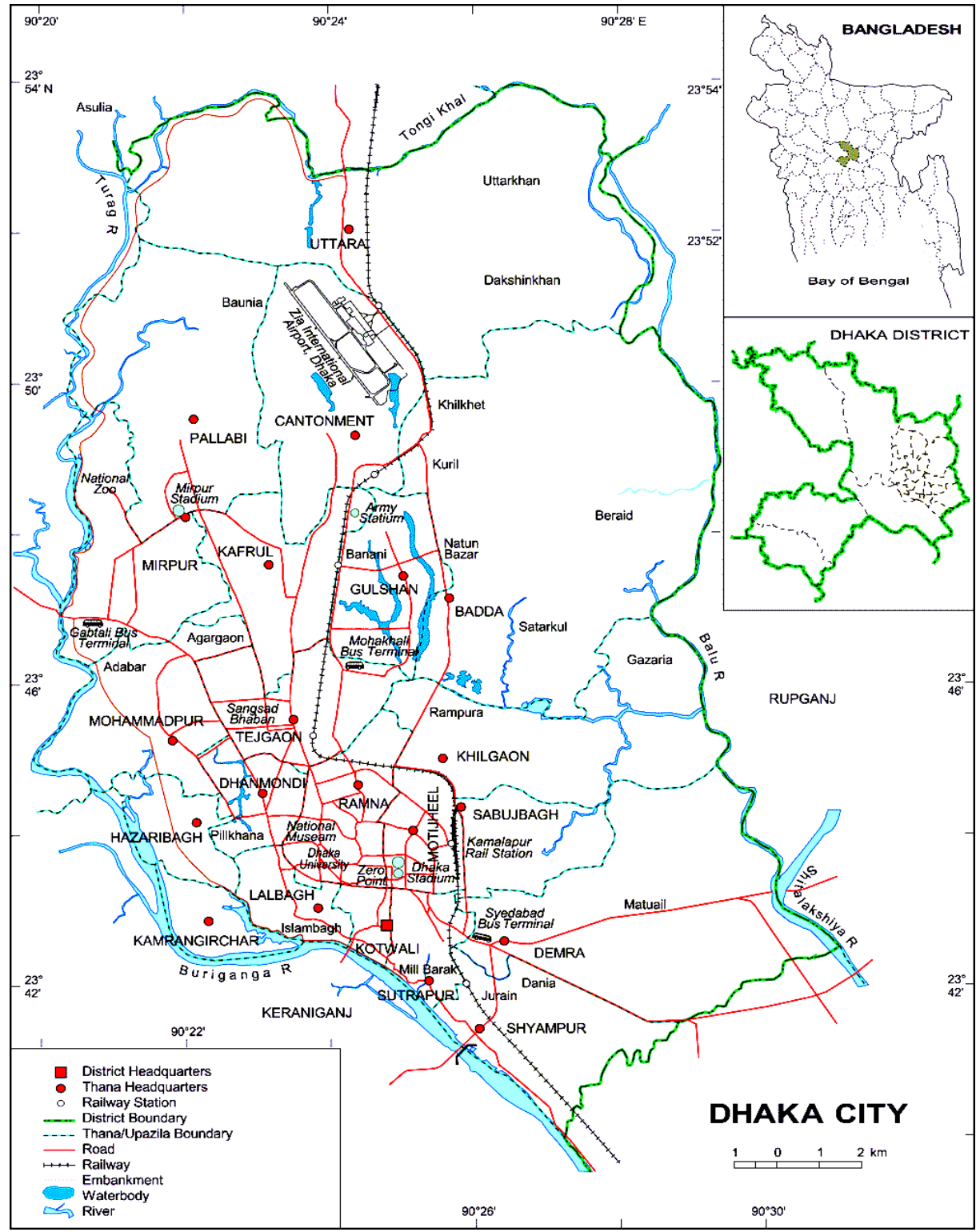

Source: Banglapedia.

Figure 1. Study area. 


\section{Definition of Wetland}

According to Ramsar Convention 'Wetland includes a wide variety of habitats such as marshes, peat ponds, floodplain, rivers and lakes and coastal areas such as salt-marshes, mangroves, and sea grass beds but also coral reefs and others marine areas no deeper than six meters at low tide, as well as human made wetlands such as waste water treatment ponds and reservoir" [15].

According to Khan et al., "wetland holds water for a significant duration sufficient to support organism adapted to life in inundated or saturated soil condition and consists of wide variety of types ranging from lakes, rivers and coastal forest to deepwater paddy fields and ponds" [9]. The built-up area of the city is traversed and surrounded by wetlands of different types.

This study indentified wetland on following categories.

1) Wetland: Wetlands comprises marshy and peaty inundated (during significant part of the year) low-lying areas of the Turag-Buriganga and the Balu floodplains [16].

2) Rivers \& Khals: Turag, Buriganga, Balu rivers and canals (local name: Khals) are belongs to this category.

\section{Data \& Software Used}

In order to compare the water bodies of Dhaka Metropolitan Area, Landsat MSS image of 1978, 1988 and Landsat TM image of 1998, 2009 were used. Spatial resolution of all of these images was $30 \mathrm{~m}$ except the image of 1978 which was $60 \mathrm{~m}$ in spatial resolution. Band 1 , 2, 3 was used for image classification. Images represent wet season of DMA as they were captured June to August on different images. It was assumed that temporal changes of water bodies remained insignificant over the period of two months, at least for city wide change analysis.

The study has been carried out under the frame work of Geographic Information System (GIS) and Remote Sensing. The image processing task has been carried out using (Earth Resource Data Analysis System) ERDAS 9.2 image processing software (Leica Geosytems Geospatial Imaging, LCC, Norcross, USA). Data on wetland features has been extracted by ERDAS Imagine 9.2 software. However, GIS task has been carried out using ArcGIS 9.3.1 version (Figure 2).

\section{Data Processing Analysis}

Geometric correction was performed on all images using a Landsat MSS image of same area from 2009 as referenced. At least 30 ground control points (GCPs) were used to register the image to Bangladesh Transverse Mercator (BTM) system. GCPs were dispersed throughout the DMA area yielding a RMS error of less than 0.5 pixels. A first order polynomial fit was applied and images were resampled to $30 \mathrm{~m}$ output pixels using nearest neighbor method. All three reflective bands were used in image classification. Parallelepiped was used as nonparametric rules.

GIS tools, such as area of interest (AOI) were applied to the data using visual analysis, reference data as well as local knowledge to split and record these covers so they more closely reflected their true classes [17]. By applying these techniques, the result obtained using supervised algorithm with Maximum likelihood technique as parametric rules and Parallelepiped as non-parametric rule which ultimately improved the output results.

In addition, geospatial data including municipal boundaries, road network, geomorphic units and elevation data were used to produce GIS layers from different sources.

A ground truth map was prepared for locating training pixels on the image and 80 reference points were collected using Global Positioning System (GPS). Magellan Triton 300 Handheld GPS was used for this task. This GPS information was overlaid with the image in GIS to select training areas and for accuracy assessments. Confusion matrix along with error of omission \& error of commission [18] was used for accuracy assessment. Over all accuracy was $87 \%$ to $92.5 \%$.

Classified images were analyzed using ArcGIS 9.3.1 software. With some additional shape file of permanent water bodies, rivers and DMA boundary, final output maps of wetlands of different years in DMA were prepared in GIS environment.

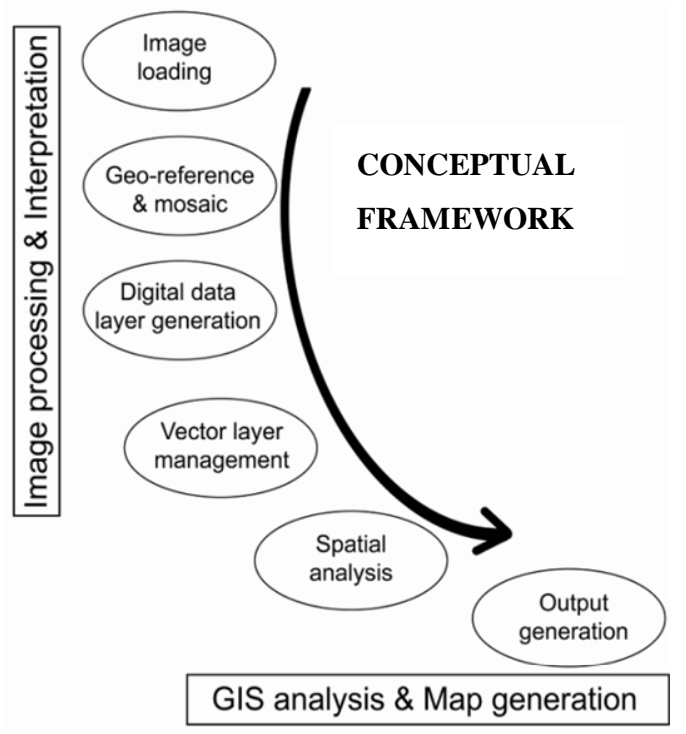

Figure 2. Conceptual framework. 


\section{Results \& Discussion}

In the beginning of urbanization phase (1978), about 29 $\mathrm{km}^{2}$ of Rivers \& Khals and about $130.17 \mathrm{~km}^{2}$ of wetlands were found in Dhaka Metropolitan Area. In 2009, only $10.28 \mathrm{~km}^{2}$ of Rivers \& Khals and $53.6 \mathrm{~km}^{2}$ of wetland is existed which is about $21 \%$ of Dhaka Metropoli$\tan$ Area. However, this figure was about 52\% in 1978.

Total $18.72 \mathrm{~km}^{2}$ of rivers and Khals were lost during this 30 years interval from 1978 to 2009 which was about $64.55 \%$ of Dhaka Metropolitan Area (Table 1). There was a depiction between 1988 and 1998 when only $7.97 \mathrm{~km}^{2}$ of Rivers and Khals were lost which was about $7.97 \%$ of total existing rivers and wetlands in 1978. In comparison to previous and following decades this number of lost is less significant. About $7.97 \mathrm{~km}^{2}$ and $8.44 \mathrm{~km}^{2}$ of Rivers \& Khals were lost in the decades of $1978-1998$ and $1998-2009$ which was about $27.48 \%$ and 29.10\% of existing rivers and Khals in 1978.

An ever increasing trend of wetlands loss is found in

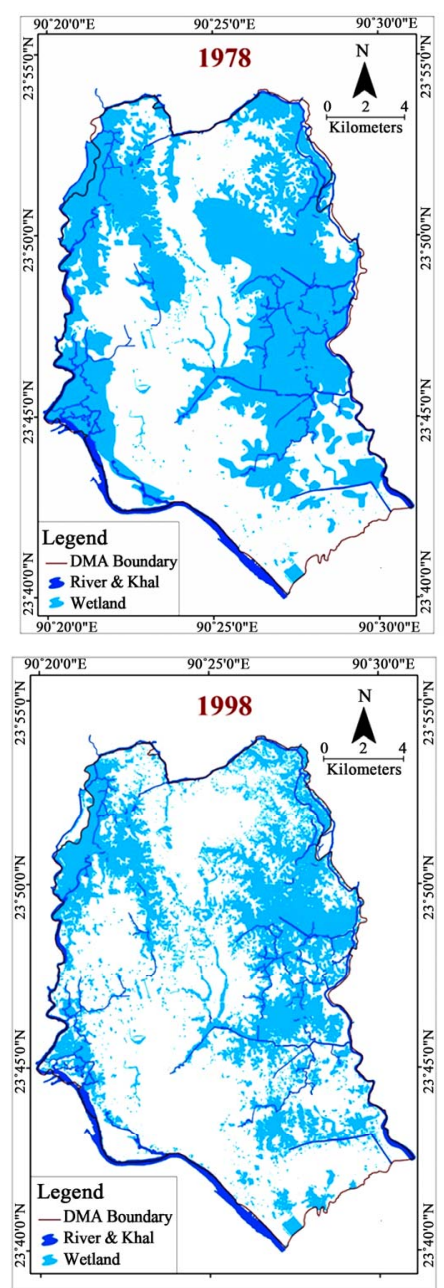

DMA between 1978 and 2009. In 1978, $130.27 \mathrm{~km}^{2}$ wetland existed which reduced to $127.85 \mathrm{~km}^{2}$ in 1988 at a rate of 1.86 in that decade. This change was quite insignificance in comparison to next decades. About 20.92 $\mathrm{km}^{2}$ of wetland was lost between 1988 and 1998 which was about $16.07 \%$ of existing wetlands in 1978 . This rate of loss of wetland in DMA was almost tripled in next decades. About $40.96 \mathrm{~km}^{2}$ of wetland was lost from 1998 to 2009 which was about $40 \%$ of existed wetland in 1978 . Overall, about $76.67 \mathrm{~km}^{2}$ of wetlands were lost between 1978 and 2009 (Figure 3).

Table 1. Wetland and Rivers \& Khals in DMA between 1978 and 2009.

\begin{tabular}{ccccc}
\hline & \multicolumn{4}{c}{ Year } \\
\cline { 2 - 5 } & 1978 & 1988 & 1998 & 2009 \\
\hline Wetlands & 130.17 & 127.85 & 106.93 & 53.6 \\
Rivers \& Khals & 29 & 21.03 & 18.72 & 10.28 \\
\hline
\end{tabular}

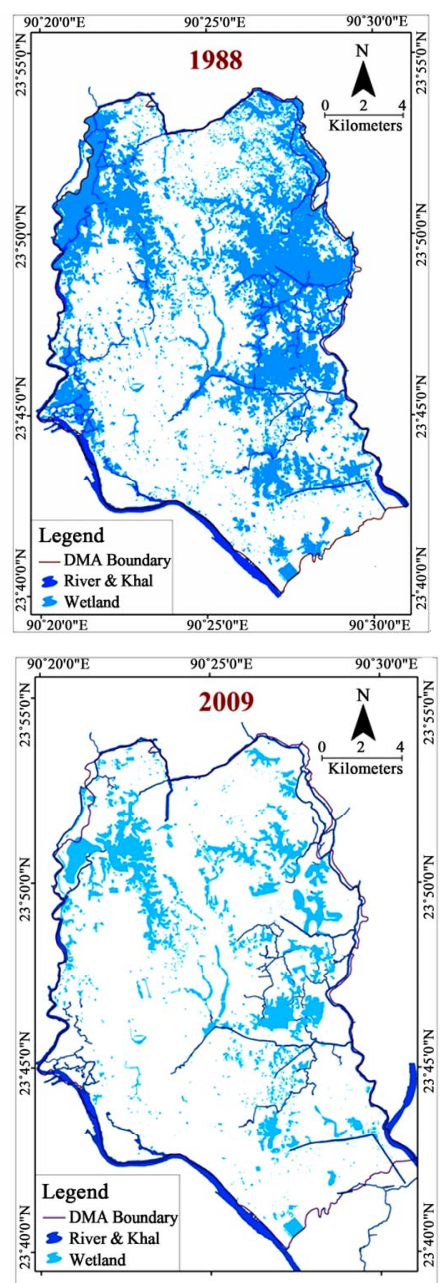

Figure 3. Wetland in Dhaka metropolitan area between 1978 and 2009. 
To sum up, about $18.72 \mathrm{~km}^{2}$ of Rivers \& Khals and about $76.67 \mathrm{~km}^{2}$ of wetland is lost during last 30 years from 1978 to 2009 (Figure 4). That means, about 60\% of existing wetlands and about $65 \%$ of Rivers \& Khals are lost in last three decades in Dhaka Metropolitan Area (DMA).

Urban expansion has been encroaching in the low-lying areas to cope with population growth, is the main reason for the reduction of wetland areas in the city. From the history of growth of the city, e.g. demonstrated that the city was remaining almost same up to the late 1980s. Area of water bodies in the western part of the city reduced to $91 \%$ of 1963 in 1990, which dropped to $63 \%$ of 1963 in 2000 [19]. Significant correlation of loss of wetland and Rivers \& Khals are also found with increasing urban population and build-up area (Table 2).

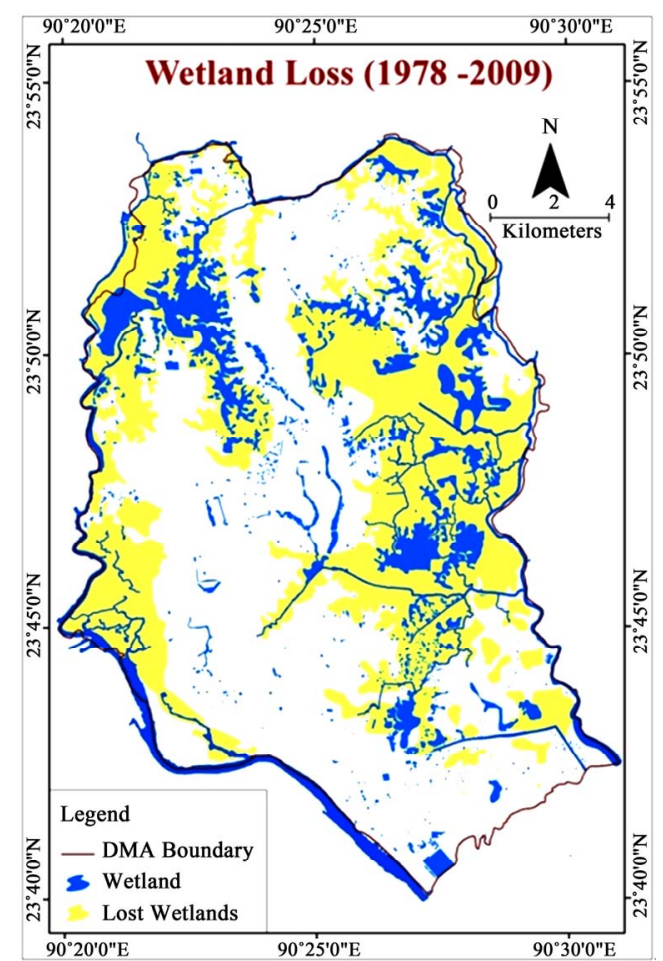

Figure 4. Wetland Loss in DMA between 1978 and 2009.

Table 2. Pearson's Correlation between variables.

\begin{tabular}{ccccc}
\hline & \multicolumn{4}{c}{ Variables } \\
\cline { 2 - 5 } & Buildup Area & Wetland & Rivers \& Khals & Population \\
\hline Buildup Area & 1.000 & -0.957 & -0.973 & 0.999 \\
Wetland & -0.957 & 1.000 & 0.908 & -0.967 \\
Rivers \& Khals & -0.973 & 0.908 & 1.000 & -0.972 \\
Population & 0.999 & -0.967 & -0.972 & 1.000 \\
\hline
\end{tabular}

\section{Impact of Loss of Wetland in Dhaka City}

\subsection{Impact on Flooding Situation of Dhaka City}

Wetlands of Dhaka metro area perform a significant role to reduce impact of flood $[20,21]$. Within the embankment area, these flood plain wetlands act as storm water retention areas. Outside the embankment they are active flood plains of adjacent rivers. Bangladesh atomic energy commission and SWMC (Bangladesh Atomic Energy Commission and SWMC, 2002) carried out a study on Ashulia flood plain area to find the impact of land filling activity on the surrounding hydrology. Findings of the research states that; the land development will increase the water level of the river, which may cause drainage problem in the areas and flow velocity of the river will also increase.

\subsection{Decrease of Ground Water Recharge Area and Ground Water Level}

According to a study conducted by SWMC (2000), about $95 \%$ of water supplied for Dhaka is extracted from underground and average annual decline of ground water within the city area during 1995 to 1999 varied from 1.02 $\mathrm{m}$ to $2.46 \mathrm{~m}$ [22]. Low land play significant role in ground water recharge function.

\subsection{Destruction of Natural Drainage System}

Lowland has dominant role in drainage function. Lowlands act as detention storage areas. Storm runoff from the surrounding areas is stored in the lowland areas [23]. The accumulated runoff is gradually drained to the peripheral rivers through drainage canals [24]. Drainage system of Dhaka city consists of forty three major Khals (canals). But many of them do not exist anymore. These Khals used to drain out the waste water (domestic and sewerage) and storm runoff to the surrounding rivers.

\subsection{Disturbance of Local Ecology and Biodiversity}

Wetlands have significant impact on local ecology and biodiversity [25]. In most of the wetland, especially the fertile flood plains have high agricultural value. Paddy and other crops are cultivated here in the dry season. During the wet season, these wetlands merge with the adjacent rivers and become fishing grounds. Agriculture and fishing in these wetlands are very much associated with the economy of local people. 


\subsection{Destruction of Aesthetically Pleasant Recreational Sites}

Wetlands within the city are mostly depression areas, marshes and natural canals. These wetlands are typically ill maintained and sites for shanty dwellings and dumping site of liquid waste [21]. On the other hand vast floodplain areas at the periphery of the city are aesthetically pleasant and well visited recreational sites.

\subsection{Increase of Impervious Surface}

A large number of researches have been done to study the impact of urbanization on flooding situation. It is believed that urbanization increases the magnitude of floods and reduces the average interval between floods that exceed a given magnitude [9]. Impact of urban development on hydrologic aspect of the site by each individual small changes may not be significant but the aggregate effect of the land development process drastically change the physical characteristics of land surface which certainly influence the drainage pattern.

\section{Conclusions}

It is true that urbanization in Dhaka city would not be stopped [13], but these should be based on further specific studies and understanding of the hydrological system of the area, not just demand driven unplanned expansion. In addition, drainage in Dhaka city is strictly controlled by land-relief and hence by gravitational drainage [26]. Special care should be given to the development and alteration of the existing water bodies so that natural hydrological condition can cope with the artificial structural actions [27]. Water management must be the first concern for any development in Dhaka city because of its natural settings.

\section{Acknowledgements}

Thanks to Mr. Sofi Ullah, Associate Professor of DU, Dr, Ishrat Islam from BUET, Ishtiak Ahmed Bhuiyan of IWFM for their contemporary guidance. Special thanks to Centre for Urban Studies (CUS), Dhaka for providing with data of DCC.

\section{References}

[1] A. H. Dani, "Dacca: A Record of Its Changing Fortunes. Ahmed Hasan Dani,” Mrs. S. S. Dani, Dhaka, 1962.

[2] J. I. C. A., "Master Plan for Greater Dhaka Protection Project (Study in Dhaka Metropolitan Area),” Japan International Cooperation Agency (JICA), Dhaka, 1991.
[3] S. U. Ahmed, "Dacca: A Study in Urban History and Development," The Riverdale Company, Glenn Dale, 1986.

[4] U. N., "Urban Geology of Dhaka, Bangladesh, Economic and Social Commission for Asia and the Pacific," Atlas of Urban Geology, United Nation (UN), New York, 1999.

[5] N. Islam, "Mega City Problems: The Case Study of Dhaka’,” In: N. Islam, Ed., Dhaka from City to Mega City, USP, Dhaka, 1996.

[6] World Bank, "Dhaka Metropolitan Development Plan Strategic Environmental Assessment,” SENES Consultants Limited in Association with Techno Consult International Ltd., Dhaka, 2007.

[7] A. S. M. M. Kamal and S. Midorikawa, "GIS-Based Geomorphological Mapping Using Remote Sensing Data and Supplementary Geoinformation: A Case Study of the Dhaka City Area, Bangladesh,” International Journal of Applied Earth Observation and Geoinformation, Vol. 6, No. 2, 2004, pp. 111-125. doi:10.1016/j.jag.2004.08.003

[8] N. Islam, "Dhaka Now: Contemporary Urban Development,” Bangladesh Geographic Society (BGS), Dhaka, 2005.

[9] N. I. Khan, “Assessment of Water Logging Conditions Using Integrated GIS and Remote Sensing Techniques: A Study of Dhaka Mega City,” Oriental Geographer, Vol. 45, No. 2, 2001, pp. 41-54.

[10] M. S. Khan, et al., "Wetlands of Bangladesh,” Bangladesh Centre for Advanced Studies (BCAS) in Association with Nature Conservation Movement (NA-COM), Dhaka, 1994.

[11] N. Islam, "Dhaka: From City to Mega City,” The University of Dhaka, Dhaka, 1996.

[12] B. B. S., "2004-Statistical Yearbook of Bangladesh, Bangladesh Bureau of Statistics (BBS)," Ministry of Planning, Government of People's Republic of Bangladesh, Dhaka, 2004.

[13] O. Mark, et al., "A Mouse GIS Study of the Drainage in Dhaka City,” Surface Water Modeling Center (SWMC), Dhaka, 2001.

[14] S. Rahman and F. Hossain, "Spatial Assessment of Water Quality in Peripheral Rivers of Dhaka City for Optimal Relocation of Water Intake Point," Water Resources Management, Vol. 22, No. 1, 2008, pp. 377-391. doi:10.1007/s11269-007-9167-y

[15] Ramsar Convention Bureau, "Ramsar Handbooks for Wise Use of Wetlands," Gland, 2000.

[16] ESCAP, “Urban Geology of Dhaka, Bangladesh,” United Nations Economic and Social Commission for Asia and the Pacific, New York, 1999.

[17] A. M. Dewan, and Y. Yamaguchi, "Landuse and Landcover Change in Greater Dhaka, Bangladesh: Using Remote Sensing to Promote Sustainable Development," Applied Geography, Vol. 29, No. 3, 2009, pp. 390-401. doi:10.1016/j.apgeog.2008.12.005

[18] T. M. Lillesand and R. W. Kiefer, "Remote Sensing and 
Image Interpretation,” John Willey and Sons, New York, 1999.

[19] A. N. M. G. Reza and M. S. Alam, "Wetland Transformation in the Western Part of Dhaka City (1963-2000)," Journal of Geography, Vol. 21, 2002, pp. 23-40.

[20] A. M. Dewan and K. T. M. Nishigaki, "Flood Hazard Delineation in Greater Dhaka, Bangladesh Using an Integrated GIS and Remote Sensing Approach,” Geocarto International, Vol. 21, No. 2, 2006, pp. 33-38. doi:10.1080/10106040608542381

[21] J. I. C. A., "Master Plan for Greater Dhaka Protection Project, Flood Action Plan, FAP 8A, Main Report and Supporting Reports I and II,” Flood Plan Coordination Agency (presently WARPO), Dhaka, 1992.

[22] W. A. S. A., "Dhaka Regional Groundwater and Subsidence Model," Dhaka Water Supply and Sewerage Authority (WASA), Dhaka, 1991.

[23] J. U. Chowdhury, M. M. Kamal, N. I. Khan and M. A. Salam, "Impact of Land Use Change upon Storm Water Drainage and Wetlands in the Eastern Part of Dhaka
City,” Integrated Water Flow Model (IWFM), Bangladesh University of Engineering \& Technology (BUET), Dhaka, 2001.

[24] J. U. Chowdhury, et al., "Impact of 1998 Flood on Dhaka City and Performance of Flood Control Works," Institute of Water and Flood Management, Bangladesh University of Engineer and Technology, Dhaka, 2001.

[25] W. J. Mitsch, R. H. Mitsch and R. E. Turner, "Wetlands of the Old and New Worlds: Ecology and Management, In Global Wetlands: Old World and New,” Elsevier Science B. V., Amsterdam, 1994.

[26] M. S. Sultana, G. M. T. Islam and Islam, Zahidul, "Preand Post urban Wetland Area in Dhaka City, Bangladesh: A Remote Sensing and GIS Analysis,” Journal of Water Resource and Protection, Vol. 1, No. 6, 2009, pp. 414421. doi:10.4236/jwarp.2009.16050

[27] T. C. Winter, "Relation of Streams, Lakes, and Wetlands to Groundwater Flow Systems," Hydrogeology Journal, Vol. 7, No. 1, 1999, pp. 28-45. doi:10.1007/s100400050178 